\title{
Privatisation Method Effects on Performance and Market Orientation of Central/Eastern European Companies*
}

Tony Cox, Graham Hooley, John Fahy, József Beracs, Krzysztof Fonfara and Boris Snoj

Privatisation in Central and Eastern Europe was introduced to encourage competition in companies with subsequent beneficial effects on company performance and market orientation. Companies have been privatised by four main methods in these countries depending on the company circumstances before privatisation and leading to different dominant stakeholders after the privatisation. The performance and market orientation of companies privatised by each method are surveyed by mailed questionnaires and differences are found that are attributable to different stakeholder influence as a result of the privatisation method.

Privatisierungen wurden in Mittel- und Osteuropa durchgeführt, um den Wettbewerb anzukurbeln, welcher in der Nachfolge positive Effekte auf Unternehmensleistung und Marktorientierung haben sollte. Unternehmen in diesen Ländern wurden nach vier verschiedenen Methoden privatisiert, abhängig davon, in welchen Umständen sich das jeweilige Unternehmen vor der Privatisierung befand. Je nach Methode führte die Privatisierung zu verschiedenartigen Hauptanteilseignern. Die Leistung und Marktorientierung von Unternehmen, die je nach einer der vier Methoden privatisiert wurden, wurde anhand von Fragebögen untersucht und es haben sich Unterschiede gezeigt, die aufgrund der verschiedenen Möglichkeiten zur Einflußnahme seitens der Anteilseigner zustande kommen.

* manuskript received: 29.06.98 revised: 21.10 .98 accepted: 21.10 .98

** Cox, Tony, born 1938, Aston Business School, Aston University, England, Department of Marketing and Law; Hooley,Graham, born 1951, Aston Business School, Aston University, England, Department of Marketing and Law; Beracs, Jozsef, born 1949, Budapest University of Economic Science Department of Marketing, Hungary; Fonfara, Krzysztof, born 1952, President Wielkopolska Business School, Poznan, Poland; Snoj, Boris, born 1947, School of Business and Economics, Department of Marketing, University of Maribor, Slovenia; Fahy, John, born 1961, University of Limerick, Department of Marketing, Ireland;

The main areas of research of all the authors are Marketing Strategy, Organisation, and Implementation with a focus on International and Central/Eastern Europe. 


\section{Introduction}

It is widely held that the privatisation of industry is necessary for a successful transition from central planning to the free market in Central and Eastern Europe (Arendarski, Mroczkowski and Sood, 1994; Buckley and Ghauri, 1994; Estrin, 1994; Hare, 1994). The major reason for the collapse of the socialist model was the economic failure of the system (Estrin 1994, Gomulka 1990) caused by lack of efficiency, effectiveness, and competition in Central/Eastern European companies (Bergson 1991, Estrin 1994) all of which are widely supposed to be addressed by the process of privatisation. Many writers identify both macroeconomic and company level improvements which should follow from the abandonment of central planning allowing decisions on prices, investment, and technology to be taken out of the hands of public policy makers and placed in the hands of managers who are responsible to private shareholders and who have more appropriate knowledge and skills (Graham and Prosser, 1987). Major macro-economic long-term effects include improvements in the national income and economic well-being (Healey, 1994; Naor, 1994). At the company level it is expected that there will be increased knowledge and more effective use of better business and technological skills. In particular companies are expected to less inefficient, more competitive (Estrin, 1994; Lieberman, 1993), and more market orientated by focusing on serving customer needs in attractive markets. The outcome of these changes is expected to be manifest in improved performance at the company level which in turn will lead to improvement in the national economy. A variety of privatisation processes have been used for companies and the purpose of the present paper is to investigate any differences in performance and market orientation between companies privatised by different methods. In what follows the main privatisation methods are discussed in order to draw out likely fundamental differences leading to expected differences in performance and market orientation. The data were collected as part of a wider survey of marketing strategies, organisation and implementation in the three countries funded by the Action for Co-operation in the Field of Economics programme.

\section{The Privatisation Processes}

Six main privatisation methods can be identified in the literature on Central/Eastern Europe (Mizsei, Mora and Csaki, 1994; Buckley and Ghauri, 1994; Tietz, 1994; McDonald, 1993; Naor, 1994; Mazur, Dolegowski, Suchnicki, and Mitroczuk 1994; Mencinger 1994). These methods are; organic privatisation, management/employee buyout, mass or voucher privatisation, flotation on a stock exchange, privatisations via state privatisation agencies, and privatisation via Foreign Direct Investment (FDI). There are, of course a number of other privatisation methods which are more country specific and hence cannot be used in this study. These methods include Direct Selling, Public Competition, Auction, and Restitution to former owners. Additionally, Organic privatisation is 
not included in the present work as it is peculiar to Poland and the research focuses on differences caused by the method of privatisation across the three countries concerned rather than on country specific issues. Similarly FDI is not included as the variety in the country of origin and investor objectives means that there is no easily identifiable common element within this group. Each of the remaining four privatisation groups has different dominant stakeholders with potentially different objectives and motivations which can be expected to influence their companies' approach to business, marketing orientation, organisational decision making and, through these, the performance of the companies.

Management/Employee Buyout is a decentralised and largely unregulated process where managers of state-owned enterprises transform them, or part of them, into privately owned businesses. This is done by the purchase of the company directly from the state and the terms of the deal are arrived at by individual negotiation (Carlin and Meyer 1992). This method was introduced in the 1980s whereby decision making power was devolved to the level of the firm by the creation of a management, workers' council and trade union triumvirate. These then initiated the privatisations by insider take-over. Clearly the major stakeholders in these companies have considerable business advantages in that they have appropriate business knowledge and expertise in the form of production processes and supplier customer networks. On privatisation they are no longer constrained by government intervention and are more able to exploit this strategic architecture. This is expected to be reflected in superior performance in the market place. It is, however, debatable whether it will lead to greater market orientation as without outside influence they are likely to carry on with their former attitudes and administrative heritage.

Mass privatisation involves the rapid privatisation of most businesses with free or very low cost shares being offered to all citizens (Lipton and Sachs 1990, Frydman and Rapaczynski 1993). While this is seen as being equitable and socially acceptable to all, there is little initial shareholder control over management and what control there is will tend to be focused on a fairly unsophisticated view of short term return on investment, wage levels, and employment. These views are supported by Schaffer (1992) who indicates that such shareholders have a considerable task in changing entrenched management attitudes and techniques before they can operate to the benefit of the shareholders, while Kornai (1992) argues that the method does nothing to develop entrepreneurs and, by implication, the performance and market orientation of the company.

In Stock Flotation enterprises are sold directly to private investors after setting the value of the property usually with the help of western investment banks. Companies likely to attract this type of investment will already be in a good competitive position. Problems have arisen because of the undeveloped stock 
markets and the limited wealth of citizens. As a result relatively few privatisations have been accomplished by this method (Hyclak and King 1994). It is expected that, as in the Western experience, one of the objectives of people investing in the stock market is to maximise their return on investment and this can lead to possible short term interests of the share holders dominating the business activities of the companies in which they invest. In some cases there has been an intermediate stage where the company is converted into joint stock with the shares initially being held by the treasury which appoints supervisors to oversee the management of the company. This emphasises the power of the stockholders in obtaining their objectives via these supervisors who are primarily looking after the interests of the stockholders.

In privatisation by State Privatisation Agencies (SPA) a large portion of stateowned property is transferred to the agencies, which are given responsibility for managing and privatising these assets. They have used several different privatisation methods including public offerings to broaden equity ownership and to stimulate the newly formed capital markets. They have also made private placements where shares were offered to a fairly limited circle of investors (e.g. the issuing bank's institutional clients). In this case of privatisation through the state privatisation agencies the government and its agents are the most influential stakeholders. In this respect it would be expected that they would encourage companies to achieve government objectives such as business and market growth but at the same time they are likely to be influenced by the legacy of central planning bureaucracy. The companies in this category tend to be those initially not attractive to the investors in the other privatisation methods due to weaker performance or positioning.

\section{Research Hypotheses}

The arguments above lead to the research hypotheses that there should be fundamental differences in the performance of companies privatised by different methods mainly due to the influence of the major stakeholders in the privatised company. Although privatisation in general is expected to lead to greater market orientation, the discussion of the literature does not provide any indications that this will be so. The issues focus on performance relative to competitors in the companies' industry so that any differences due to industry are eliminated.

H1. There will be considerable performance improvement in the case of Management and Employee Buyouts: These companies will enjoy greater managerial freedom, greater practical business knowledge, and familiarity with local business networks. In addition with financial responsibility now resting with the managers and employees there will be greater incentive to perform better financially in terms of profit possibly through cost control and improved efficiency. 
H2. There will be little performance improvement in Mass Privatisation Companies: Because of lack of shareholder power and control due to the large number of shareholders and diffuse ownership, it is expected that autonomous managers might focus on survival objectives. There will also a tendency for former management to stay in place with little change in their former attitudes. There will be little incentive for them to take risks or innovate and overall little change in strategies followed would be expected. As the process develops, however, investment funds will buy the small investor shares leading to a greater concentration of power as has happened in the Czech Republic and to some extent in Hungary.

H3. There will be limited performance improvement in companies privatised by Stock Flotation albeit from a high performance base: Here there is likely to be limited scope for radical improvement because, in order to attract the large scale investment needed for stock flotation, they would already be in a good competitive position. Improvement could also be limited by the strong influence of new owners buying in either for asset stripping or for long term investment. However, these firms would be expected to continue to perform relatively strongly in their sectors with added incentives of pressure from shareholders and the benefits of cash injection.

\section{H4. There will be little performance improvement in companies privatised} via the State Privatisation Agencies from an already low performance base: Performance here is likely to be low because they were sold via the State Privatisation Agencies as no buyers could be found by other means. This method also brings with it problems of political influence in the privatisation process leading to possible emphasis on employment rather than profit and continuing entrenched managerial and stakeholder attitudes with little change from their former State Owned Enterprises (SOE) attitudes.

H5. There will be no significant difference in the Market Orientation of companies privatised by different methods. In the introduction it was noted that one of the consequences of privatisation was to increase market orientation of companies. However, few arguments were evident in the literature or the discussion above that would indicate a pattern of difference in the market orientation between the different privatised company categories.

\section{Methodology}

The methodology consisted of a qualitative phase and a quantitative phase. In the qualitative phase semi-structured interviews were carried out with key personnel in 32 companies in the three countries in order to gain in depth insight into changes in the macro and task environments in which the companies operated, their marketing strategies and organisation, and their market orientations. The interviews were conducted with the people fulfilling the 
functions of chief executive and other functional managers by experienced native academic colleagues enabling the interviews to be carried out in the respondents' own language by interviewers familiar with their own cultural and country context. The results of these interviews were used to inform the design of a mailed questionnaire which was sent to a total of 3000 companies representative of the company sector and company size profiles in Hungary and Slovenia, and 2000 in Poland. In the survey as a whole 1619 usable responses were received, with 589 from Hungary, 401 from Poland, and 629 from Slovenia with corresponding response rates of $19.6 \%, 13.4 \%$, and $21.0 \%$ respectively. The responses were also checked for non-response bias using a follow up telephone survey. A subsample was used in the present work which was restricted to former SOEs that had been fully privatised using domestic privatisation and to companies with between 100 and 500 employees. In this way influences from foreign management and differences caused by company size were minimised. The focus on medium sized privatised companies led to relatively small samples limiting the extent to which the results are generalisable.

\section{Findings}

\subsection{Business Focus}

The discussion above indicates that differences are to be expected in the overall business focus of companies privatised by different methods and in the performance of these companies. Respondents were asked to indicate their business focus by ranking the importance of a series of business objectives on a scale of 1 (most important) to 7 (least important). A seven point scale was used throughout for consistency with the widely accepted Marver and Slater scales on Market Orientation. Table 1 shows the responses for each of the objectives where important signifies that the issue was ranked 1 or 2 , neutral that it was ranked 3, 4 or 5, and unimportant that it was ranked 6 or 7. In overall terms it can be seen that profit is by far the main business focus with $68.7 \%$ indicating that it is important. Sales volume was the next most important issue (46.1\%).

These are the performance indicators traditionally used in a free market economy to indicate the short term health of a company. Following these two foci there is a group of foci with almost equal frequency of reported importance, these are ROI (26.8\%), unit production cost (26.3\%), and cash flow $(25.6 \%)$. Clearly this indicates an emphasis on survival and putting the company on a sound financial footing. It is significant that market share is quoted by only $23.8 \%$ of respondents as being important and might be seen to indicate that longer term marketing goals are less significant than immediate survival goals. 
Table 1 Business Objectives

\begin{tabular}{|c|c|c|c|c|c|c|}
\hline Factor & & $\begin{array}{c}\text { Total } \\
\mathrm{n}=399\end{array}$ & $\begin{array}{l}\text { Buyout } \\
n=112\end{array}$ & $\begin{array}{l}\text { Mass } \\
\mathrm{n}=161\end{array}$ & $\begin{array}{l}\text { Stock } \\
n=72\end{array}$ & $\begin{array}{l}\text { SPA } \\
n=54\end{array}$ \\
\hline Profit & Important & $68.7 \%$ & $66.1 \%$ & $68.9 \%$ & $77.8 \%$ & $61.1 \%$ \\
\hline \multirow[t]{2}{*}{$\mathrm{Sig}=\mathrm{ns}$} & Neutral & $23.1 \%$ & $26.8 \%$ & $23.0 \%$ & $13.9 \%$ & $27.8 \%$ \\
\hline & Unimportant & $8.3 \%$ & $7.1 \%$ & $8.1 \%$ & $8.3 \%$ & $11.1 \%$ \\
\hline Sales Volume & Important & $46.1 \%$ & $46.4 \%$ & $44.7 \%$ & $45.8 \%$ & $50.0 \%$ \\
\hline \multirow[t]{2}{*}{$\operatorname{Sig}=n s$} & Neutral & $39.1 \%$ & $38.4 \%$ & $41.6 \%$ & $40.3 \%$ & $31.5 \%$ \\
\hline & Unimportant & $14.8 \%$ & $15.2 \%$ & $13.7 \%$ & $13.9 \%$ & $18.5 \%$ \\
\hline Market Share & Important & $23.8 \%$ & $27.7 \%$ & $19.3 \%$ & $30.6 \%$ & $20.4 \%$ \\
\hline \multirow[t]{2}{*}{ Sig $=n s$} & Neutral & $45.9 \%$ & $39.3 \%$ & $48.4 \%$ & $44.4 \%$ & $53.7 \%$ \\
\hline & Unimportant & $30.3 \%$ & $33.0 \%$ & $32.3 \%$ & $25.0 \%$ & $25.9 \%$ \\
\hline ROI & Important & $26.8 \%$ & $25.0 \%$ & $25.5 \%$ & $31.9 \%$ & $27.8 \%$ \\
\hline \multirow[t]{2}{*}{ Sig $=n s$} & Neutral & $48.1 \%$ & $46.4 \%$ & $49.7 \%$ & $44.4 \%$ & $51.9 \%$ \\
\hline & Unimportant & $25.1 \%$ & $28.6 \%$ & $24.8 \%$ & $23.6 \%$ & $20.4 \%$ \\
\hline Cash Flow & Important & $25.6 \%$ & $40.2 \%$ & $19.9 \%$ & $23.6 \%$ & $14.8 \%$ \\
\hline $\mathrm{Sig}=0.001$ & Neutral & $52.4 \%$ & $46.4 \%$ & $57.1 \%$ & $52.8 \%$ & $50.0 \%$ \\
\hline $\operatorname{chi}=23.63$ & Unimportant & $22.1 \%$ & $13.4 \%$ & $23.0 \%$ & $23.6 \%$ & $35.2 \%$ \\
\hline Unit Costs & Important & $26.3 \%$ & $21.4 \%$ & $35.4 \%$ & $18.1 \%$ & $20.4 \%$ \\
\hline $\mathrm{Sig}=0.01$ & Neutral & $45.9 \%$ & $46.4 \%$ & $42.2 \%$ & $56.9 \%$ & $40.7 \%$ \\
\hline chi $=16.43$ & Unimportant & $27.8 \%$ & $32.1 \%$ & $22.4 \%$ & $25.0 \%$ & $38.9 \%$ \\
\hline $\begin{array}{r}\text { Provide } \\
\text { Employment for } \\
\text { Local Population }\end{array}$ & Important & $12.8 \%$ & $13.4 \%$ & $13.7 \%$ & $9.7 \%$ & $13.0 \%$ \\
\hline \multirow[t]{2}{*}{ Sig $=n s$} & Neutral & $20.1 \%$ & $18.8 \%$ & $22.4 \%$ & $20.8 \%$ & $14.8 \%$ \\
\hline & Unimportant & $67.2 \%$ & $67.9 \%$ & $64.0 \%$ & $69.4 \%$ & $72.2 \%$ \\
\hline
\end{tabular}

Not surprisingly in these circumstances the provision of employment for the local population comes low in the list of overall priorities. These overall figures give an indication of the relatively precarious nature of privatised business in Central Europe as a whole with all companies being driven by a common economic climate. There are only two significant differences between companies privatised by different means. The first is that of cash flow where 
management/employee buyouts indicate that cash flow is more important than companies privatised by other methods $(40.2 \%)$. These are likely to be smaller companies that originally were not privatised by stock and state privatisation schemes. As a result they are likely to be more vulnerable to failure through lack of cash flow by not having the resources to cushion themselves against this problem. The second significant difference is the greater emphasis put on the reduction of unit costs for the mass privatised companies (35.4\%). A possible explanation is that these were not as attractive to individual institutional buyers precisely because of their high cost operations and are having to focus on this in order to give themselves the opportunity to succeed.

\subsection{Performance Relative to Competitors}

Respondents were asked to indicate whether they had performed better, the same, or worse than their competitors for a series of indicators. The responses for each privatisation category are given in table 2 where the percentages given are the column percentages. It is striking that a large percentage were unable to answer the questions, with the percentages ranging from $22.8 \%$ to $42.6 \%$ depending on the question. While it is not surprising that the ability to provide employment for the local population was not known, the lack of knowledge on their competitive performance with respect to the more fundamental performance indicators showed a considerable deficit in their competitor monitoring. Important differences are evident between privatisation categories and without exception the companies privatised by mass privatisation which have the least percentage of don't knows while it is those companies privatised through the State Privatisation Agencies which exhibit the largest ignorance concerning the various performance indicators.

As the figures above show, companies privatised by mass privatisation are the most competitively focused with their State Privatisation Agency privatised counterparts the least competitively focused of the four categories. However, significant differences in actual competitive performance are observed between each of the privatisation methods. With the exception of profit and the provision of gainful employment for the local population, the management/employee buyout companies perform better than the others. In the case of profit performance and the provision of gainful employment, it is the mass privatisation companies which perform the best (23.6\% and $16.8 \%$ respectively) reporting better performance than their competitors. With only one exception companies privatised by a stock flotation perform the worst with respect to their competitors. The exception to this is in the reduction of unit costs where the State Privatisation Agency privatisations have fewest respondents reporting a better performance $(5.6 \%)$.

In order to focus on the issues raised in the research issues, it is useful to discuss the performance characteristics of each type of company separately. Buyout 
companies focus more on improving cash flow than other types of company. This may be seen as of prime importance as these companies are most vulnerable to lack of resources and the removal of state support given that managers have probably stretched themselves to the limit in the purchase of the company and have little flexibility in the way of financial buffers. Compared with other company types, more respondent companies outperformed competitors in sales volume, market share, ROI, cash flow, and unit costs. This outstanding performance is seen to be associated with greater managerial efficiency in that they are more knowledgeable about their performance in profit, sales volume, and ROI exhibiting the fewest don't know responses in all these areas in the year on year figures. Undoubtedly they are aided in their business activities by local knowledge and familiar business network as well as being less constrained by central planning with the privatised status. This entirely supports research hypothesis one.

Mass privatised companies have objectives focused on reducing unit production costs which might indicate more of an internal focus on improvement of and the importance of experience effects on long term profitability. It is also noticeable that they exhibit more knowledge of competitor performance than other company types and, in support of research hypothesis two, they report better competitive performance in the area of employment for the local population than other types of company. This is in keeping with the fact that many of their stakeholders are private individuals for whom this is important. They also report good competitive performance in profit indicating that the incumbent managers are not motivated by former non free market attitudes. This is in contradiction of the expectations of research hypothesis two. Companies privatised by stock flotation are the least likely to report better competitive performance in all performance indicators than all the other company types except in the area of unit costs. As already suggested speculative investors could be attracted to them because of their advantageous position. The poor performance could reflect an arms length speculative investor attitude to reap short term benefits with little involvement in the company and the lack of managerial and technical input. This possibly indicates that investors are more focused on short term gain than in the longer term development of the company. The companies privatised via the State Privatisation Agencies, as predicted by research hypothesis four, are the worst performers in most respects of the four privatisation methods under study here. As discussed above this may be because the political influence might be more dominant in the privatisation process. They are the least knowledgeable about competitors in terms of all performance indicators. Thus they appear to be least interested in either short term performance or long term competitive development. This is especially true in the case of unit costs compared with their competitors, showing lack of interest in efficiency and, as predicted in research hypothesis four, perhaps reflects a legacy of former SOE attitudes. 
Table 2 Performance Relative to Competitors

\begin{tabular}{|c|c|c|c|c|c|c|}
\hline Factor & & $\begin{array}{c}\text { Total } \\
\mathrm{n}=399\end{array}$ & $\begin{array}{l}\text { Buyout } \\
n=112\end{array}$ & $\begin{array}{l}\text { Mass } \\
\mathrm{n}=161\end{array}$ & $\begin{array}{l}\text { Stock } \\
\mathrm{n}=72\end{array}$ & $\begin{array}{l}\text { SPA } \\
n=54\end{array}$ \\
\hline Profit & Better & $19.3 \%$ & $21.4 \%$ & $23.6 \%$ & $9.7 \%$ & $14.8 \%$ \\
\hline Sig $=0.001$ & Same & $35.8 \%$ & $33.9 \%$ & $42.9 \%$ & $33.3 \%$ & $22.2 \%$ \\
\hline \multirow{2}{*}{ chi $=35.09$} & Worse & $16.3 \%$ & $12.5 \%$ & $18.6 \%$ & $19.4 \%$ & $13.0 \%$ \\
\hline & Don't know & $28.6 \%$ & $32.1 \%$ & $14.9 \%$ & $37.5 \%$ & $50.0 \%$ \\
\hline Sales Volume & Better & $25.1 \%$ & $31.3 \%$ & $23.6 \%$ & $16.7 \%$ & $27.8 \%$ \\
\hline $\mathrm{Sig}=0.001$ & Same & $37.1 \%$ & $32.1 \%$ & $46.6 \%$ & $36.1 \%$ & $20.4 \%$ \\
\hline \multirow{2}{*}{ chi $=30.36$} & Worse & $15.0 \%$ & $8.9 \%$ & $17.4 \%$ & $18.1 \%$ & $16.7 \%$ \\
\hline & Don't know & $22.8 \%$ & $27.7 \%$ & $12.4 \%$ & $29.2 \%$ & $35.2 \%$ \\
\hline Market Share & Better & $19.0 \%$ & $25.0 \%$ & $16.1 \%$ & $15.3 \%$ & $20.5 \%$ \\
\hline Sig $=0.007$ & Same & $40.9 \%$ & $36.6 \%$ & $50.9 \%$ & $36.1 \%$ & $25.9 \%$ \\
\hline \multirow[t]{2}{*}{ chi $=22.82$} & Worse & $16.5 \%$ & $10.7 \%$ & $17.4 \%$ & $20.8 \%$ & $20.4 \%$ \\
\hline & Don't know & $23.6 \%$ & $27.7 \%$ & $15.5 \%$ & $27.8 \%$ & $33.3 \%$ \\
\hline ROI & Better & $10.0 \%$ & $12.5 \%$ & $9.3 \%$ & $6.9 \%$ & $11.1 \%$ \\
\hline Sig $=0.006$ & Same & $37.3 \%$ & $33.0 \%$ & $46.0 \%$ & $36.1 \%$ & $22.2 \%$ \\
\hline \multirow[t]{2}{*}{ chi $=22.97$} & Worse & $16.0 \%$ & $14.3 \%$ & $18.6 \%$ & $18.1 \%$ & $9.3 \%$ \\
\hline & Don't know & $36.6 \%$ & $40.2 \%$ & $26.1 \%$ & $38.9 \%$ & $57.4 \%$ \\
\hline Cash Flow & Better & $15.5 \%$ & $20.5 \%$ & $15.5 \%$ & $8.3 \%$ & $14.8 \%$ \\
\hline Sig $=0.001$ & Same & $33.6 \%$ & $32.1 \%$ & $43.5 \%$ & $30.6 \%$ & $11.1 \%$ \\
\hline \multirow[t]{2}{*}{ chi $=38.52$} & Worse & $15.5 \%$ & $10.7 \%$ & $18.0 \%$ & $19.4 \%$ & $13.0 \%$ \\
\hline & Don't know & $35.3 \%$ & $36.6 \%$ & $23.0 \%$ & $41.7 \%$ & $61.1 \%$ \\
\hline Unit Costs & Better & $14.5 \%$ & $17.9 \%$ & $17.4 \%$ & $9.7 \%$ & $5.6 \%$ \\
\hline Sig $=0.001$ & Same & $39.8 \%$ & $33.9 \%$ & $48.4 \%$ & $36.1 \%$ & $31.5 \%$ \\
\hline \multirow[t]{2}{*}{ chi $=27.13$} & Worse & $11.8 \%$ & $11.6 \%$ & $11.2 \%$ & $16.7 \%$ & $7.4 \%$ \\
\hline & Don't know & $33.8 \%$ & $36.6 \%$ & $23.0 \%$ & $37.5 \%$ & $55.6 \%$ \\
\hline $\begin{array}{r}\text { Provide Employment for } \\
\text { Local Population } \\
\end{array}$ & Better & $12.5 \%$ & $10.7 \%$ & $16.8 \%$ & $8.3 \%$ & $9.3 \%$ \\
\hline Sig $=0.038$ & Same & $38.6 \%$ & $33.0 \%$ & $44.7 \%$ & $38.9 \%$ & $31.5 \%$ \\
\hline \multirow[t]{2}{*}{ chi $=17.78$} & Worse & $6.3 \%$ & $7.1 \%$ & $6.8 \%$ & $6.9 \%$ & $1.9 \%$ \\
\hline & Don't know & $42.6 \%$ & $49.1 \%$ & $31.7 \%$ & $45.8 \%$ & $57.4 \%$ \\
\hline
\end{tabular}




\section{Market Orientation}

In order to study the market orientation of companies privatised by different means, respondents were asked to indicate the importance of various factors concerned with market orientation, on a seven point scale, with 1 being the most important and 7 the least important. The factors in the survey were based on Narver and Slater's (1990) construct for market orientation comprising customer orientation, competitor orientation, and internal communication and integration. The original Narver and Slater factors were augmented in this case by additional questions found to be important in the qualitative phase of this survey. In tables $3 \mathrm{a}, 3 \mathrm{~b}$, and $3 \mathrm{c}$ the means of the responses on the seven point scale are shown for each privatisation category and the significance of differences is calculated using a one way ANOVA and the least squares difference criteria following Narver and Slater's methodology.

\subsection{Customer Orientation}

Significant differences between the company types are apparent, as measured by Scheffe's criteria for differences in the means of the responses, although no generic trend is apparent. The companies privatised by buyout are less committed to monitoring customer needs (mean 3.16) than the other groups of company and are less driven by the creation of customer satisfaction (mean 2.25) than either the voucher privatised or stock flotation privatised companies. This could indicate that they are relying on their historic relations and perhaps more internally focused. It is also seen that the State Agency Privatised companies are more likely (mean 1.65) that the others to put major effort into building stronger relationships with key customers and influencers. This could be explained by this type of company being more dependent on their former customers while in state ownership which could have been one of the attractions for their purchase from the state controlled agency.

The mass privatised companies are seen to recognise less the importance of creating satisfied customers than the buyout companies (mean 2.83). This is also true when the importance of improving external market performance (mean 4.30), and business strategies being driven by increasing value to customers (mean 2.96) is considered and where they are also less customer focused than the stock flotation companies.

\subsection{Competitor Orientation}

Again no general pattern emerges from the data and no difference between the privatisation categories observed with two exceptions only. One exception being the smaller importance placed by the mass privatised companies (mean 3.40) than by the others on targeting customers when there is the opportunity for competitive advantage. 
Table 3 a Customer Orientation

\begin{tabular}{|c|c|c|c|c|c|c|}
\hline \multicolumn{7}{|l|}{ Customer Orientation } \\
\hline Factor & Sig & $\mathrm{F}$ & Buy Out & Mass & Stock & $\begin{array}{c}\text { State } \\
\text { Agency }\end{array}$ \\
\hline $\begin{array}{l}\text { Our commitment to serving } \\
\text { customer needs is closely monitored }\end{array}$ & .0001 & 7.04 & $\begin{array}{c}\mathrm{n}=106 \\
3.16 \\
>2,3,4\end{array}$ & $\begin{array}{c}\mathrm{n}=158 \\
2.38\end{array}$ & $\begin{array}{c}\mathrm{n}=71 \\
2.62\end{array}$ & $\begin{array}{c}\mathrm{n}=53 \\
2.30\end{array}$ \\
\hline $\begin{array}{r}\text { We put major effort into building } \\
\text { stronger relationships with key } \\
\text { customers and influencers }\end{array}$ & .0001 & 7.21 & $\begin{array}{c}\mathrm{n}=106 \\
2.35\end{array}$ & $\begin{array}{l}\mathrm{n}=157 \\
2.68 \\
>3,4\end{array}$ & $\begin{array}{c}\mathrm{n}=70 \\
2.21\end{array}$ & $\begin{array}{c}\mathrm{n}=54 \\
1.65 \\
<1,2,3\end{array}$ \\
\hline $\begin{array}{l}\text { Senior management in all functions } \\
\text { recognises the central importance of } \\
\text { creating satisfied customers }\end{array}$ & .0025 & 4.85 & $\begin{array}{c}\mathrm{n}=107 \\
2.17\end{array}$ & $\begin{array}{c}\mathrm{n}=158 \\
2.83 \\
>1\end{array}$ & $\begin{array}{c}\mathrm{n}=71 \\
2.51\end{array}$ & $\begin{array}{l}\mathrm{n}=54 \\
2.43\end{array}$ \\
\hline $\begin{array}{r}\text { We put greater emphasis on } \\
\text { improving our external market } \\
\text { performance than on improving } \\
\text { internal efficiencies }\end{array}$ & .0041 & 4.49 & $\begin{array}{c}\mathrm{n}=105 \\
3.75\end{array}$ & $\begin{array}{c}\mathrm{n}=158 \\
4.30 \\
>1,3\end{array}$ & $\begin{array}{c}\mathrm{n}=70 \\
3.59\end{array}$ & $\begin{array}{c}\mathrm{n}=52 \\
3.90\end{array}$ \\
\hline $\begin{array}{l}\text { Business strategies are driven by } \\
\text { increasing value for customers }\end{array}$ & .0166 & 3.46 & $\begin{array}{c}\mathrm{n}=108 \\
2.53\end{array}$ & $\begin{array}{c}\mathrm{n}=157 \\
2.96 \\
>1,3\end{array}$ & $\begin{array}{c}\mathrm{n}=72 \\
2.38\end{array}$ & $\begin{array}{c}\mathrm{n}=54 \\
2.54\end{array}$ \\
\hline $\begin{array}{l}\text { Objectives and strategies driven by } \\
\text { creation of customer satisfaction }\end{array}$ & .0218 & 3.25 & $\begin{array}{c}\mathrm{n}=108 \\
2.25 \\
>2,3\end{array}$ & $\begin{array}{c}\mathrm{n}=159 \\
1.79\end{array}$ & $\begin{array}{c}\mathrm{n}=72 \\
1.86\end{array}$ & $\begin{array}{c}\mathrm{n}=52 \\
1.85\end{array}$ \\
\hline $\begin{array}{r}\text { Top management regularly visits } \\
\text { important customers }\end{array}$ & $\mathrm{ns}$ & & $\begin{array}{c}\mathrm{n}=107 \\
2.91\end{array}$ & $\begin{array}{c}n=160 \\
2.66\end{array}$ & $\begin{array}{c}\mathrm{n}=69 \\
2.88\end{array}$ & $\begin{array}{c}\mathrm{n}=52 \\
2.94\end{array}$ \\
\hline $\begin{array}{r}\text { Managers understand now } \\
\text { employees can contribute to value } \\
\text { for customers }\end{array}$ & ns & & $\begin{array}{c}\mathrm{n}=105 \\
2.90\end{array}$ & $\begin{array}{c}\mathrm{n}=159 \\
2.77\end{array}$ & $\begin{array}{c}n=71 \\
2.85\end{array}$ & $\begin{array}{c}\mathrm{n}=53 \\
3.13\end{array}$ \\
\hline $\begin{array}{r}\text { Information about customer needs } \\
\text { and requirements is collected } \\
\text { regularly }\end{array}$ & $\mathrm{ns}$ & & $\begin{array}{c}\mathrm{n}=108 \\
2.86\end{array}$ & $\begin{array}{c}\mathrm{n}=158 \\
2.77\end{array}$ & $\begin{array}{c}\mathrm{n}=72 \\
3.15\end{array}$ & $\begin{array}{c}\mathrm{n}=53 \\
2.74\end{array}$ \\
\hline
\end{tabular}

1=Buyout, 2=Mass Privatisation, 3=Stock Flotation, 4=State Agency Privatisation

The only other exception is that the state privatisation agency companies differentiate their offerings from their competitors less than the buyout companies perhaps reflecting more former large sized former SOEs in this category than in the others and an established network of influential customers. 


\subsection{Internal Implementation}

Only two differences between the responses on company types are observed. In the first instance, it is in the buyout companies that sales people are the least likely to share information about important competitors (mean 3.88). This clearly could be due either to lack of competitor information, which is not entirely consistent with the findings of the section above on competitor orientation, or it could be due to a smaller amount of integration of business information in this type of company. Again, no general pattern emerges from the data, with the only other significant difference between company types being the relative impact of interdepartmental rivalry in the companies privatised by stock flotation (mean 3.00).

Table $3 b$ Competitor Orientation

\begin{tabular}{|c|c|c|c|c|c|c|}
\hline Competitor Orientation & & & & & & \\
\hline $\begin{array}{r}\text { Customers are targeted when we } \\
\text { have an opportunity for competitive } \\
\text { advantage }\end{array}$ & .0210 & 3.28 & $\begin{array}{c}\mathrm{n}=105 \\
2.90\end{array}$ & $\begin{array}{c}\mathrm{n}=154 \\
3.40 \\
>1,3,4\end{array}$ & $\begin{array}{r}\mathrm{n}=69 \\
2.93\end{array}$ & $\begin{array}{l}\mathrm{n}=53 \\
2.74\end{array}$ \\
\hline $\begin{array}{l}\text { We try to differentiate our offerings } \\
\text { from competitors on factors we } \\
\text { know are important to customers }\end{array}$ & .0457 & 2.70 & $\begin{array}{c}\mathrm{n}=107 \\
2.45\end{array}$ & $\begin{array}{c}\mathrm{n}=158 \\
2.74\end{array}$ & $\begin{array}{l}\mathrm{n}=70 \\
2.87\end{array}$ & $\begin{array}{c}\mathrm{n}=53 \\
3.15 \\
>1\end{array}$ \\
\hline $\begin{array}{r}\text { Competitive strategies are based on } \\
\text { understanding customer needs }\end{array}$ & ns & & $\begin{array}{c}\mathrm{n}=107 \\
2.64\end{array}$ & $\begin{array}{c}\mathrm{n}=157 \\
2.60\end{array}$ & $\begin{array}{c}\mathrm{n}=70 \\
2.47\end{array}$ & $\begin{array}{l}\mathrm{n}=53 \\
2.49\end{array}$ \\
\hline $\begin{array}{r}\text { We achieve rapid response to } \\
\text { competitive actions }\end{array}$ & ns & & $\begin{array}{c}\mathrm{n}=108 \\
2.92\end{array}$ & $\begin{array}{c}\mathrm{n}=160 \\
3.03\end{array}$ & $\begin{array}{l}\mathrm{n}=71 \\
2.75\end{array}$ & $\begin{array}{l}\mathrm{n}=53 \\
3.28\end{array}$ \\
\hline $\begin{array}{l}\text { Information about competitor } \\
\text { activities is collected regularly }\end{array}$ & ns & & $\begin{array}{c}\mathrm{n}=109 \\
3.13\end{array}$ & $\begin{array}{c}\mathrm{n}=157 \\
3.31\end{array}$ & $\begin{array}{r}\mathrm{n}=72 \\
3.00\end{array}$ & $\begin{array}{c}\mathrm{n}=53 \\
2.91\end{array}$ \\
\hline $\begin{array}{l}\text { We conduct regular benchmarking } \\
\text { against major competitor offerings }\end{array}$ & ns & & $\begin{array}{c}\mathrm{n}=110 \\
2.61\end{array}$ & $\begin{array}{c}\mathrm{n}=159 \\
2.65\end{array}$ & $\begin{array}{c}\mathrm{n}=71 \\
2.58\end{array}$ & $\begin{array}{c}\mathrm{n}=54 \\
2.48\end{array}$ \\
\hline $\begin{array}{r}\text { Decisions are guided by long term } \\
\text { considerations rather than short run } \\
\text { expediency }\end{array}$ & ns & & $\begin{array}{c}\mathrm{n}=109 \\
2.79\end{array}$ & $\begin{array}{c}\mathrm{n}=156 \\
2.92\end{array}$ & $\begin{array}{r}\mathrm{n}=69 \\
3.06\end{array}$ & $\begin{array}{c}\mathrm{n}=53 \\
3.00\end{array}$ \\
\hline
\end{tabular}

1=Buyout, 2=Mass Privatisation, 3=Stock Flotation, 4=State Agency Privatisation 
Table 3c Internal Implementation

\begin{tabular}{|c|c|c|c|c|c|c|}
\hline Internal Implementation & & & & & & \\
\hline $\begin{array}{r}\text { Customer satisfaction is frequently } \\
\text { assessed }\end{array}$ & ns & & $\begin{array}{c}\mathrm{n}=105 \\
3.82\end{array}$ & $\begin{array}{c}\mathrm{n}=158 \\
3.45\end{array}$ & $\begin{array}{c}\mathrm{n}=70 \\
3.61\end{array}$ & $\begin{array}{l}\mathrm{n}=53 \\
3.57\end{array}$ \\
\hline $\begin{array}{r}\text { Sales people share information about } \\
\text { competitors }\end{array}$ & .0000 & 8.47 & $\begin{array}{c}\mathrm{n}=107 \\
3.88 \\
>2,3,4\end{array}$ & $\begin{array}{c}\mathrm{n}=156 \\
2.83\end{array}$ & $\begin{array}{c}\mathrm{n}=71 \\
3.14\end{array}$ & $\begin{array}{l}\mathrm{n}=52 \\
3.08\end{array}$ \\
\hline $\begin{array}{r}\text { Rivalry between departments is not } \\
\text { allowed to get in the way of serving } \\
\text { customers effectively }\end{array}$ & .0397 & 2.80 & $\begin{array}{c}\mathrm{n}=107 \\
2.64\end{array}$ & $\begin{array}{c}\mathrm{n}=156 \\
2.31\end{array}$ & $\begin{array}{c}\mathrm{n}=70 \\
3.00 \\
>2\end{array}$ & $\begin{array}{l}n=51 \\
2.69\end{array}$ \\
\hline $\begin{array}{r}\text { Business functions are integrated to } \\
\text { serve market needs }\end{array}$ & .2091 & 1.52 & $\begin{array}{l}108 \\
2.86 \\
>2\end{array}$ & $\begin{array}{l}157 \\
2.46\end{array}$ & $\begin{array}{c}69 \\
2.71\end{array}$ & $\begin{array}{c}52 \\
2.63\end{array}$ \\
\hline $\begin{array}{r}\text { Information about customers is freely } \\
\text { communicated throughout the } \\
\text { company }\end{array}$ & ns & & $\begin{array}{c}\mathrm{n}=106 \\
4.02\end{array}$ & $\begin{array}{c}\mathrm{n}=159 \\
3.91\end{array}$ & $\begin{array}{c}\mathrm{n}=71 \\
3.96\end{array}$ & $\begin{array}{c}\mathrm{n}=52 \\
3.60\end{array}$ \\
\hline $\begin{array}{l}\text { Top management regularly discuss } \\
\text { competitors' strengths and weaknesses }\end{array}$ & ns & & $\begin{array}{c}\mathrm{n}=107 \\
3.26\end{array}$ & $\begin{array}{c}\mathrm{n}=158 \\
3.24\end{array}$ & $\begin{array}{c}\mathrm{n}=70 \\
3.04\end{array}$ & $\begin{array}{l}\mathrm{n}=53 \\
3.40\end{array}$ \\
\hline $\begin{array}{r}\text { Close attention is given to after sales } \\
\text { service }\end{array}$ & ns & & $\begin{array}{c}\mathrm{n}=102 \\
3.51\end{array}$ & $\begin{array}{c}\mathrm{n}=158 \\
3.35\end{array}$ & $\begin{array}{c}\mathrm{n}=70 \\
3.43\end{array}$ & $\begin{array}{l}\mathrm{n}=50 \\
3.44\end{array}$ \\
\hline $\begin{array}{l}\text { Reward structures are closely related } \\
\text { to external market performance }\end{array}$ & $\mathrm{ns}$ & & $\begin{array}{c}\mathrm{n}=108 \\
3.06\end{array}$ & $\begin{array}{c}\mathrm{n}=159 \\
3.33\end{array}$ & $\begin{array}{c}\mathrm{n}=71 \\
3.20\end{array}$ & $\begin{array}{l}\mathrm{n}=54 \\
3.22\end{array}$ \\
\hline
\end{tabular}

1=Buyout, 2=Mass Privatisation, 3=Stock Flotation, 4=State Agency Privatisation

\subsection{Conclusions and Discussion of Market Orientation}

In support of research hypothesis five there is no significant difference between the overall market orientation of companies privatised by different methods, nor in the major components of the Narver and Slater construct, namely customer orientation, competitor orientation, and internal implementation. There are, however, differences in some of the individual factors which can be largely explained by stakeholder influences. Buyout companies are less driven by creation of customer satisfaction than the other types and in terms of internal implementation of market orientation they use less monitoring of customer needs relying on historic experience. This latter is consistent with the buyout managers already being familiar with the business and exploiting the same systems as they used previously. It is also less likely for salespeople to share information about customers. This might imply that they espouse customer satisfaction but in fact don't monitor their needs regularly, relying instead on 
their historic knowledge. Mass privatised companies are less likely to put major effort into building stronger relationships with key customers with less management recognition of creating satisfied customers. They appear to be internally focused with less emphasis on improving external performance than on improving internal efficiencies and less driven by creation of customer satisfaction. This lack of customer orientation is also evident in that they are less likely to target customers when have competitive advantage. Thus the voucher companies appear to be more internally focused than the others with an emphasis on internal efficiency. SPA companies use little product differentiation with the implication, given their likely previous large market share in their former SOE status and is consistent with them relying on established customer networks. This asset clearly could have been one of the main attractions for their sale via the SPA in the first place. Stock Flotation companies are slightly more likely to display interdepartmental rivalry than the other companies but with this exception are not differentiated from the other company types. The explanation for this is not entirely obvious.

\section{Overall Conclusions and Comments}

The five hypotheses are largely supported, within the limitations of the data noted earlier, with the differences in performance being largely explicable by the dominant stakeholder characteristics. Buyout companies out perform all the other company categories probably because of the managers prior knowledge of the industry, markets, and processes. Mass privatised companies focus on the reduction of costs and the provision of employment for the local population. In contradiction to expectations, they exhibit good performance in profit with respect to their competitors and the proposition that with little influence from shareholders, managers will retain former non free market attitudes is unfounded. Companies privatised by stock flotation exhibit the least competitive performance apparently possibly because of their former advantageous position and because of the focus of their investors on return rather than company development. The SPA privatised companies perform worst on all performance indicators in accordance with the hypotheses and which can be explained by the continuing legacy of state planning attitudes by their major stakeholders and political influences. Thus it is seen that the performance of companies privatised by different means does exhibit significant differences and that these differences are not inconsistent with the propositions contained in the hypotheses section of this paper concerning the state of the company before privatisation and the attitudes and influences of their major stakeholders.

As expected there is no significant difference in the overall market orientation of companies privatised by different means or in terms of customer orientation, competitor orientation, and internal implementation. Where differences do occur 
in individual components of the Narver and Slater construct, they are again not inconsistent with expected stakeholder influences.

\section{References}

Arendarski, A., Mroczkowski, T and Sood J.(1994): A Study of the Redevelopment of Private Enterprise in Poland: Conditions and Policies for Continuing Growth, Journal of Small Business Management, 32 (3), pp 40-51.

Bergson A.(1991): The USSR before the fall. How poor and why, Journal of Economic Perspectives, vol 5, pp29-44.

Buckley, P. and Ghauri, P, (Eds).(1994): The Economics of Change in the East and Central Europe. London, Academic Press.

Carlin W \& Mayer C.(1992): Restructuring Enterprises in Eastern Europe, Economic Policy, vol 15, pp312-352.

Estrin, S., (Ed).(1994): Privatisation in Central and Eastern Europe, London, Longman.

Frydman R, Rapaczynski A and Earle JS.(1993): The Privatisation Process in Central Europe, Central European, University Press.

Gomulka S.(1991): The Causes of Recession Following Stabilisation, Comparative Economic Studies, vol 33, pp71-89.

Graham C \& Prosser T.(1987): Privatising Nationalised Industries, Constitutional Issues and New Legal Techniques, Modern Law Review, vol 50, pp16-51.

Healey, N. (1994): The Transition Economies of Central and Eastern Europe: A Political, Economic, Social, and Technological Analysis, Columbia Journal of World Business, 29(1), pp62-70.

Hyclak TJ \& King AE. (1994): The Privatisation Experience in Eastern Europe, Basil Blackwell Ltd., Oxford.

Kornai J. (1992): The Principles of Privatisation in Eastern Europe, The Economist, vol 140, pp153-176.

Lieberman, I. (1993): Privatisation: The Theme of the 1990s: An Overview, Columbia Journal of World Business, 28 (1), pp8-18.

Lipton D \& Sachs J. (1990): Privatisation in Eastern Europe: The Case of Poland, Brookings Papers on Economic Activity, vol 2, pp293-341.

Mazur, M., Dolegowski, T., Suchnicki, J., and Mitroczuk, I. (1994): Privatisation in Poland, In Rondinelli, D., (Ed), Privatisation and Economic Reform in Central Europe, pp175-207.

McDonald, K. (1993): Why Privatisation is Not Enough, Harvard Business Review, 71 (3), 49-59.

Mencinger, J. (1994): Decentralised Versus Centralised Privatisation: The Case of Slovenia, In Rondinelli, D., (Ed), Privatisation and Economic Reform in Central Europe, pp93-105.

Mizsei, K., Mora, M., and Csaki, G. (1994): Experiences with Privatisation in Hungary: The Early Transition Period, In Rondinelli, D., (Ed), Privatisation and Economic Reform in Central Europe, pp40-67. 
Naor, J. (1994): Marketing Under Newly Emerging East European and Soviet Conditions, In Buckley, P. and Ghauri, P, (Eds), (1994): The Economics of Change in the East and Central Europe, London, Academic Press.

Narver, J. and Slater, S. (1990): The Effect of Marketing Orientation on Business Profitability, Journal of Marketing, 54, pp20-35.

Shaffer, M. (1993): Polish Economic Transformation: From Recession to Recovery and the Challenges Ahead, Business Strategy Review, 4 (3), pp 53-69.

Tietz, B. (1994): The Opening-up of Eastern Europe: The Implications for West European Business, The Economics of Change in East and Central Europe, pp55-90, London, Academic Press. 